\title{
Being Resilient Between the Region and the Higher Education System? Views on Regional Higher Education Institutions in Estonia and Finland
}

\author{
Jari Kolehmainen, Heli Kurikka, Anne Keerberg, \\ and Garri Raagmaa
}

\section{INTRODUCTION}

The chapter explores the resilience of regional higher education institutions (RHEIs), which must be resilient because they are exposed to changes in the higher education system (HES), such as with policies of

J. Kolehmainen $(\bowtie) \cdot$ H. Kurikka

Tampere University, Seinäjoki, Finland e-mail: jari.kolehmainen@tuni.fi

H. Kurikka e-mail: heli.kurikka@tuni.fi

A. Keerberg Tallinn University of Technology, Tallinn, Estonia e-mail: anne.keerberg@nooruse.edu

(C) The Author(s) 2022

R. Pinheiro et al. (eds.), Towards Resilient Organizations and Societies, Public Sector Organizations, https://doi.org/10.1007/978-3-030-82072-5_10 
'picking winners' that emphasize excellence, efficiency and centralizing resources (Pinheiro \& Young, 2017; Sørensen et al., 2016). RHEIs are also impacted by the development trajectories of their regions. However, the literature on education system resiliency in the context of economic development (shocks) is limited (e.g. Moran, 2016; Pinheiro \& Young, 2017; Postiglione, 2011), neglecting RHEIs' role in regional resilience.

There is a relatively wide consensus that the presence of universities stimulates economic development and improves the resilience of regions. HEIs have a significant impact on the businesses and organizations of their region (Vaessen \& Velde, 2003), opening it up to the wider world. HEIs may serve as the global pipelines bridging social capital, contributing to regional development (Bathelt et al., 2004) and interpreting new ideas, knowledge and technologies. HEIs may also assume the role of experts in local decision-making bodies (Arbo \& Benneworth, 2007), act as strategic partners and institutional entrepreneurs (Raagmaa \& Keerberg, 2017) and contribute to rural innovation (Charles, 2016).

Typically, resilience (Chapter 1 , in this volume) is divided into two main types: (1) bouncing back to a state of normalcy after a crisis and (2) the flexibility to adjust without crossing the thresholds of identity. For regions, adaptive resilience, a third type of resilience, is possible (Martin \& Sunley, 2015). Hence, we are interested in the conditions that motivate or even force RHEIs to choose their resilience strategy. A RHEI may contribute proactively to the development of its own operational environment, that is, the surrounding region, by acting as an institutional entrepreneur (cf. Benneworth et al., 2017; Cai \& Liu, 2020). Institutional entrepreneurs are actors that challenge existing institutions or create new ones (DiMaggio, 1988). However, having the role of a local opinion leader would theoretically lead RHEIs to lock in, assuming a defensive position and losing the strategic vision of the future. Therefore, we attempt to examine whether and under what circumstances RHEIs are sustainable in the long run. We address the following questions:

\footnotetext{
G. Raagmaa

Tartu University, Tartu, Estonia

e-mail: garri.raagmaa@ut.ee
} 
- How resilient are RHEIs, and what kind of organizational strategies do they use?

- What is the relationship between RHEIs, their locational regions and the HE system from the perspective of resilience?

The answers to these questions are sought by conducting a qualitatively case study on two small RHEIs in the peripheral regions of Kuressaare, Estonia and Seinäjoki, Finland. The case studies are a result of a long-lasting research process in which versatile case study methodologies and data sets have been applied: (1) desk research of policy documents and statistics; (2) data provided by the representatives of RHEIs (e.g. memos, planning documents); (3) semistructured interviews and (4) action research directly involved in the activities of the RHEIs' directors, board members and employees.

The earliest data sets were gathered for both case studies in 2013 as a part of two projects: the TIPS programme ${ }^{1}$ in Estonia and ITU research programme ${ }^{2}$ in Finland. These data include eight interviews for the Kuressaare case and 11 interviews for Seinäjoki. The interviewees were mainly local HEI leaders, representatives of local and regional authorities and business representatives. Since then, the data have been updated and augmented with a large number of interviews and other written and electronic material up to the year 2019. Some interviews were conducted repeatedly, giving a longitudinal character to the case studies. In the very end of this research process, the manuscript was commented on by two representatives of the case RHEIs to verify and validate our theoretical approach and empirical findings.

${ }^{1}$ Teadus- ja innovatsioonipoliitika seire programm (TIPS) [Research and Innovation Policy Monitoring Program], funded by Estonian Ministry of Science and Education.

${ }^{2}$ Innovaatioympäristöjen tutkimus- ja kehittämishanke (ITU) [Research Programme on Local and Regional Innovation Environments], funded by University of Tampere, Regional Council of South Ostrobothnia, City of Seinäjoki, Into Seinäjoki Ltd, University Consortium of Seinäjoki and Higher Education Fund of South Ostrobothnia. 


\section{THEORETICAL BACKDROP}

\section{Organizational Resilience and Coevolution in Different Contexts}

Here, we construct a theoretical framework to understand how the resilience of RHEIs may be shaped. We begin by outlining organizational resilience, continue with the interaction of RHEI and regions and study the role of the HES. Organizational resilience (OR) is usually defined as the organizations' capability to recover from external shocks. However, this is a narrow view of resilience. More detailed and enriched definitions exist:

Resilience is the emergent property of organisational systems that relates to the inherent and adaptive qualities and capabilities that enable an organisations adaptive capacity during turbulent periods. The mechanisms of organisational resilience thereby strive to improve an organisation' situational awareness, reduce organisational vulnerabilities to systemic risk environments and restore efficacy following the events of a disruption. (Burnard \& Bhamra, 2011, p. 5587)

Here, the emphasis is not only on the individual and sudden shocks in terms of resilience, but attention is paid to incremental changes. Following this reasoning, OR can be understood as organizations' capability to cope with their own operational environment over time. Coping does not only refer to surviving or pure adaptation: it also involves the idea of strong agency. Indeed, RHEIs are organizations capable of anticipating the future, preparing themselves for it and shaping their own operational environment. RHEIs may not only interact with other institutions (formal and informal practices), but also proactively create new and modify existing ones (see, e.g. DiMaggio, 1988) because they play an important role in transforming social values and shaping society (Cai \& Liu, 2020).

Denyer (2017) created the 'tension quadrant' model on OR based on an extensive literature review (181 academic articles). The model splits OR into behaviours that are defensive (maintaining the status quo) or progressive (innovating and taking risks) and those that are consistent or flexible. These four viewpoints form an integral part of the OR 'tension quadrant' (Fig. 10.1). Consistent and flexible behaviours relate to March's (1991) organizational learning, where an exploitative type of learning refers to efforts aimed at incremental change and continuity, 


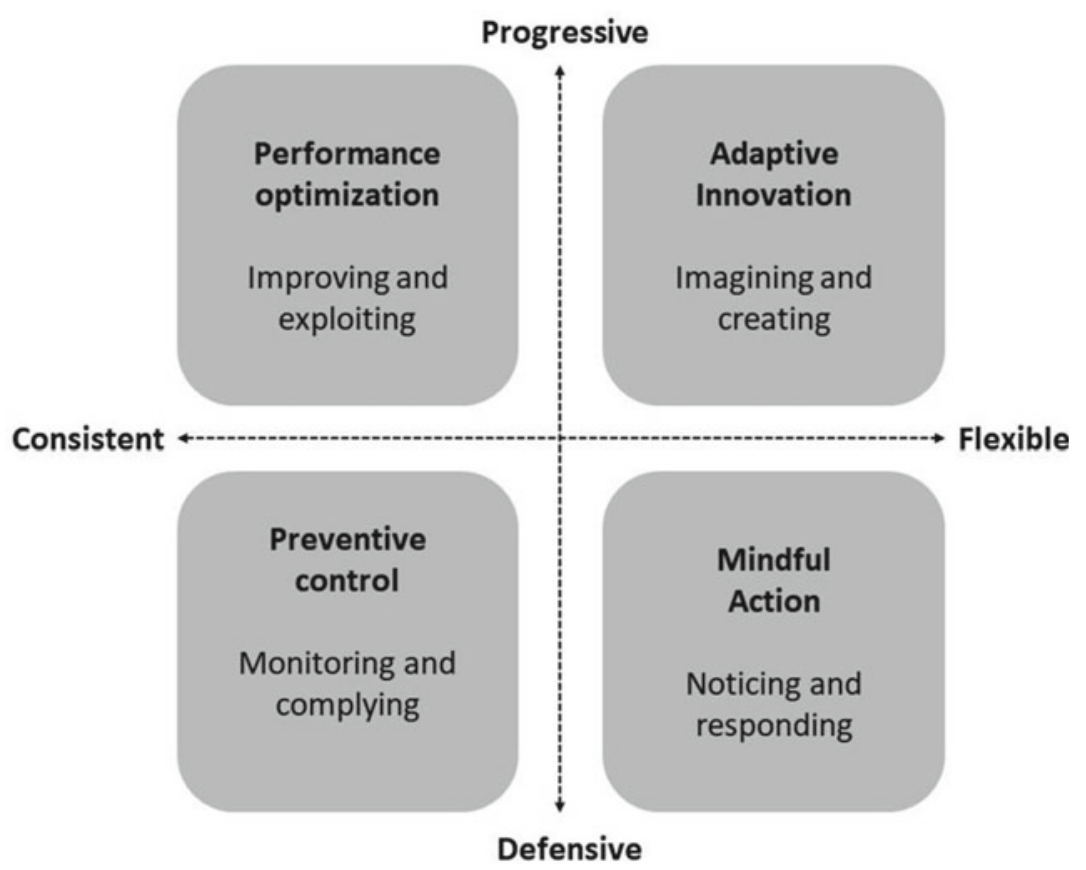

Fig. 10.1 Dimensions of organizational resilience. Source Denyer (2017, p. 10)

whereas explorative learning is about seeking new paths aiming at more radical changes and innovations.

Denyer (2017) identified four strategic ways of thinking about OR: preventative control (defensive consistency), mindful action (defensive flexibility), performance optimization (progressive consistency) and adaptive innovation (progressive flexibility). A resilient organization utilizes all ways of thinking depending on the situation. Sometimes, it is crucial to defend the integrity of an organization against external interests (Selznick, 1984), and in some situations, a more progressive strategy is called for.

The concept of coevolution means that the relationship between agents and their environment is bidirectional. If an agent is merely adapting to changes, the relationship is not coevolutionary. From an evolutionary perspective, coevolution is a matter of series of variation and retention processes (Lewin \& Volberda, 1999; Sotarauta \& Kautonen, 2007; Sotarauta \& Srinivas, 2006). Coevolution calls for agency, which is also an 
integral part of OR. As Sotarauta and Srinivas (2006, p. 319) stated, 'The co-evolutionary view suggests that both environment and agency are important in the course of evolution'. Agency is the link between OR of RHEIs, that is, their strategic ways to act, and the coevolution of the determinants constructing both the resilience of RHEIs and their surrounding region and the whole HES.

\section{Regional Higher Education Institutions and Regional Resilience}

Regional resilience is a complex phenomenon that determines how a region responds to a shock or disturbance and under what circumstances it will be able to develop further. Following the 2008-2010 global financial crisis, the resilience concept began to be used in regional studies. According to Martin (2012), a region is resilient if it can resist recessionary shocks, recover quickly from them, re-orientate and renew its growth path towards a new growth trajectory. We define the resilience of a region as equal its capability to adapt to the changes in its economic environment.

This kind of adaptive resilience thinking is typical for evolutionary economic geography, which sees regional economies as continuous adapting processes and stable equilibrium states as nonexistent (Martin \& Sunley, 2015). This is why so-called bounce-back resilience (see Chapter 1 in this volume) is not easily applied to regions. Regions adjust to new kinds of situations, for example, by creating, diversifying and upgrading industrial paths (Grillitsch \& Asheim, 2018). This can lead to changes in regional economic structures like the industrial mix. Therefore, the second type of resilience-an adjustment without crossing the threshold of identity-does not suit regions as such because there is the question of what the 'thresholds' of regional economy are.

A regional economy can go through major changes, and exactly because of this, a region can be called 'resilient'. This is what Martin's (2012) 're-orientation' means. Thus, regional resilience would be a region's capacity to maintain economic performances despite shocks by adapting regional structures and functions; this can also be seen as a 'bounce forward' (Martin \& Sunley, 2015, p. 4). Pike et al. (2010, p. 62) studied the mechanisms of regional resilience and found that 'adaptability' is the key issue, which here means the capacity of a region to break free from old paths and ability to find new ones. This also resonates well with 
March's (1991) study of organizational learning and its concept of exploration, that is, seeking new avenues and breaking with the past. Bristow and Healy (2014) emphasized that this process of regional reorientation calls for agency.

The components of regional resilience can be divided into five categories: (1) industrial and business structure, (2)labour market conditions, (3)financial arrangements, (4)agency/decision making and (5)governance arrangements (Martin \& Sunley, 2015). These factors explain much of a region's ability to resist and recover from shocks, but also its ability to recognize and benefit from positive changes.

Peripheral regions have many disadvantages compared with core locations. The logic of economy is mostly based on the benefits of agglomerations and accessibility of core regions (Isaksen, 2015). In this respect, the resilience of peripheries faces challenges. HEIs can play a crucial role in shaping regional resilience. Karlsen et al. (2011) and Trippl et al. (2016) pointed out that Nordic peripheries succeeded in compensating for organizational thinness with the institutional thickness provided by public policies. Here, thickness refers to the presence of dynamic clusters and support organizations that can help in developing new industries based on scientific knowledge, while thinness is about the absence of this (Tödtling \& Trippl, 2005). There was a policy boom of setting up RHEIs to enrich regional knowledge capacity in many European regions in the 2000s (Hedin, 2009; OECD, 2007). The evolution of RHEI networks in the Nordic countries was the result of several decades of lasting regional and education policy, the resilience of RHEIs and their surrounding regions developing in a coevolutionary manner.

The role of RHEIs in facilitating learning and adaptation processes (Gunasekara, 2006) can be considered particularly vital in peripheral regions characterized by low densities and limited access. Smallness and remoteness can be associated with closeness and kindness-generating rich social capital might be an advantage: capable people with a high knowledge level empowered by high social capital and trust may increase the benefits of a small region. The potentially good and lively community life is often a breeding ground for innovation. In such regions, the quadruple helix model combining HE actors, public authorities, business community and local social community groups may be at the very heart of knowledge-based regional development (Kolehmainen et al., 2016). Peripheries in general-save for one-company towns that might be extremely vulnerable-are less influenced by global shocks that arrive 
with a delay and in an already modified form. RHEIs located in the peripheries act not only as educators and technology transfer units, but also as institutional entrepreneurs that create new institutions and modify entrepreneurial ecosystem (Raagmaa \& Keerberg, 2017; TIPS, 2015).

Peripheral regions are organizationally thin (Tödtling \& Trippl, 2005), giving more weight to RHEIs and allowing them to convince local decision makers more easily to implement institutional changes in a shorter time. RHEIs located in small towns tend to be relatively more active in contributing to regional development actions. In addition, regional leadership in policy and business have a significant role in establishing and supporting the development of the RHEI as an initiative maker and funder (Sotarauta, 2014, 2015). However, institutional lock-in and ceasing development are a possible threat because of limited human resources and the pressure of local actors of RHEIs, meaning consequently a much higher role of proactive leadership than institutionally thick well-staffed urban cores.

\section{Regional Higher Education Institutions and the Higher Education System}

RHEIs are regional actors, but they are also a part of the national and global HES. Analysing the resilience of an entire HES by using explicitly the concept of resilience appears to be scarce in the literature. Naturally, there is a plethora of studies on the transformation, reforms, change and adaptation of the HEIs and the whole HE system (Stensaker \& Benner, 2013; Stensaker et al., 2012; Vukasovic et al., 2012). However, despite different geographical and field-specific traditions and development paths, the university has proven to be very persistent in retaining its basic ideals, such as its knowledge-based nature and open and genuine discourse and interaction (e.g. Rothblatt \& Wittrock, 1993). Universities are institutions, not instruments for reaching certain externally set agendas (Olsen, 2007), even if entrepreneurs and even governmental bodies occasionally criticize universities about their rigidity and far less innovative action than society would expect.

Still, as Pinheiro and Young (Chapter 7, this volume) pointed out, in the European context, universities are seen as strategic actors of the knowledge-based economy. These notions call forth the 'Hesburgh paradox': how traditional and rigid institutions like universities produce revolutionary change (see Clark, 1983, p. 182). In this light, HEIs could 
choose a defensive strategy to maintain the status quo. Still, all HEIs are not alike; there are great variations depending on size, age, profile, location strategies and so forth. For example, there is a growing number of 'entrepreneurial universities' (Benneworth \& Nieth, 2018; Benneworth et al., 2017; Clark, 1998) aiming to become more adaptive and engaged with public institutions, businesses and civil society. Even the old conservative universities are changing and adapting alongside the changing governmental policy goals and funding conditions, reflecting the more profound changes in economy and society (see, e.g. Tapper \& Palfreyman, 2011).

The HES consists of different kinds of HEIs that coevolve together. This holds true for the RHEIs, which are only a small but a particular part of a national HES. Pinheiro and Young (2017, p. 122) defined an HES as 'an emergent, self-organizational, and dynamic complex system where the relations among the actors or agents are characterized as nonlinear, with the relations among system elements and with other systems being coevolutionary'. HESs are usually permanent, and thus, it is relevant to interpret their resilience as their capability to adapt in a changing environment without compromising their core essence and values, such as social justice, competence, liberty and national loyalty (Clark, 1983). These basic values may be misaligned or manifest differently in different parts of HESs.

It is also worth noting that there are many kinds of pulling and pushing forces within and among HEIs and within HE systems and policies. Those forces create tensions and result in the coexistence, even coevolution, of multiple, sometimes contradictory, logics. Certain approaches are more dominant than others in certain periods of time. As Pinheiro and Young (this volume) argued, the prevailing European HE policies and systems emphasize short-term efficiency, instrumentalist objectives, rankings and other managerialist practices challenging the resilient nature of universities based on requisite variety, loose-coupledness and slack (see also Pinheiro \& Young, 2017). This may not be a good orientation for RHEIs because they do not usually fit into the tight, managerial university moulds because of their distinctive characteristics.

There are few other specific issues in the relation between RHEIs and the whole HES from the perspective of resilience. First, RHEIs are strongly engaged with local and regional stakeholders and needs. However, they are also a part of the whole HES and have ambitions 
to influence it. On the other hand, RHEIs are institutionally dependent on their 'mother universities', that is, the central administrations of those universities that are responsible for the operations of RHEIs or are members of RHEIs that are network organizations. Therefore, RHEIs have both direct and indirect relations with the ministries and other key institutions within the HES. However, the strategic objectives of RHEIs and their 'mother universities' may differ. Consequently, especially for RHEIs, influencing the whole HES is a delicate balance between their own objectives and their mother universities' objectives.

The second notion relates to the size of RHEIs. Universities have to operate in a rapidly globalizing competitive marketplace (Olsen, 2007), and the recent trends include merging HEIs into larger entities (see, e.g. Välimaa et al., 2014). Large organizations tend to have better resources to face adversities, but small organizations can have other benefits, such as low bureaucracy, effective internal communication, quick decision making and rapid strategic adapting (Vossen, 1998). Hypothetically, choosing a progressive or defensive strategy depends on the size and status of a HEI. Fairly young and small RHEIs can hardly be defensive; instead, they need to be progressive and 'entrepreneurial'. Naturally, this is a simplistic view because the actual lived strategies and strategic practices are context and time specific. Still, it can be argued that when RHEIs are belonging and steered by ever larger mother universities, this becomes a potential source of tensions, and RHEIs should find a way to act within the universities and the whole HES.

\section{EMPIRICAL SECTION}

\section{Case 1. Kuressaare, Estonia}

\section{Regional HEIs in the Estonian Higher Education System}

The Estonian HES is the third smallest among OECD countries. Currently, there are $20 \mathrm{HEIs,} \mathrm{including} \mathrm{six} \mathrm{public} \mathrm{universities,} \mathrm{one}$ private university, eight state professional HEIs and five private professional HEIs. The universities run six regional units. The number of students reached its peak in 2010 and has been declining because of tightened quality requirements and demographic development in recent years. Estonia is undergoing a period of demographic transition; the domestic $\mathrm{HE}$ enrolments are falling, but the number of international students is growing (see, e.g. OECD, 2019). 
The development path of the Estonian HES has been eventful because of a number of reforms. There were six national HEIs in Estonia in 1990. Then, demand for market economy professionals increased, and several mainly private HEIs were established. By 2001, there were 49 HEIs that ran 30 regional units outside the old university cities Tallinn and Tartu. There was no national legislation or policy regulating the creation of RHEIs in Estonia; instead, they resulted from agreements between local initiative-takers and the universities. Setting up RHEIs in Estonia was the result of several market-led, societal, governance and leadership-related factors. The process was strongly supported by regional authorities, county governments and/or city governments that lobbied ministries and university rectors (Raagmaa \& Keerberg, 2017).

\section{Saaremaa and Kuressaare College}

Saaremaa is an island in the Baltic Sea, and with its surrounding islands, it makes up about $7 \%$ of Estonian territory and $2 \%$ of the population $(33,000$ inhabitants). The distance from the county seat Kuressaare (13,000 inhabitants) to Tallinn is $217 \mathrm{~km}$, a journey of $4.5 \mathrm{~h}$, including the seaway. Saaremaa's economy is dominated by services, but the share of manufacturing in regional GDP is increasing. The main industries are food, machinery, electronics, rubber and plastics. More than $70 \%$ of industrial output is exported. The Development Strategy of Saaremaa County has identified health tourism and small craft building as new growth areas. The latter forms advanced R\&D-based industry micro cluster accounting over $90 \%$ of the turnover and $80 \%$ of the employment nationwide (Sääsk, 2018). Over the last three years, some 150 new highly qualified jobs have been created in companies involved in shipbuilding (Saare Development Centre, 2018).

Kuressaare College of the Tallinn University of Technology (KC), the smallest based on its students numbers, was created in 1999. Saaremaa entrepreneurs were active in the process because they realized that otherwise, they could not employ the necessary specialists. Seven Estonian university colleges started joint collaborative action since 2003, and intensive lobby work with the Minister for Regional Affairs resulted in a national university college programme in 2006. The rectors of six public universities of Estonia signed an agreement in 2008 aiming to develop a network of regional centres of competence (Ülikoolide, 2008). As a result, the EU-financed regional competence centres programme was launched in 2009. 


\section{Kuressaare College and Regional Resilience}

The regional competence network of Saaremaa, led by Kuressaare College, was created in 2009. Small craft building was agreed to be the most promising area for smart specialization, so the Small Craft Competence Centre (SCC) was initiated (see Reidolf et al., 2011). The purpose was to accumulate and develop related knowhow and provide better facilities to train marine engineers. In parallel, the development of small craft building curriculum started and enrolled its first students in 2010 . The proposal for EU funding was approved, and the SCC was officially established as a part of $\mathrm{KC}$ in 2011.

Universities were directly communicating with regional businesses when their local staff was conveying knowledge demanded by the community. In return, the (business) community provided feedback and input for education and research activities. At the heart of realizing these mutual benefits were place-based initiatives and intensive regional networking. Making these things happen also called for capable leadership that convinced the community to develop a certain sector with university support. In addition, regional partners had to find additional resources to finance the regional activities of the universities.

In 2014, the new Estonian Regional Development Strategy endorsed cooperation with the universities. Ironically, at this point, regional cooperation was no longer an urgent priority for the universities because they were facing increasing pressure for excellence and competition for enrolling international students and EU research grants. This has been a challenge for RHEIs. Despite this policy mismatch, the network of Estonian regional colleges has had a significant role in increasing the development capacity of different regions (TIPS, 2015). College towns have been growth centres for future-oriented industries because of the accumulation of competences and institutions able to support ongoing industrial transition. KC progressively and flexibly promotes adaptive innovation, and it has a coevolutionary relationship with the region.

\section{Kuressaare College and the Evolving Higher Education System}

In 2016, a new Tallinn University of Technology (TalTech) development plan was adopted aiming to optimize its structure. Thus, TalTech merged $\mathrm{KC}$ as its smallest unit with the TalTech Maritime Academy in January 2017. The merger was also a potential threat. However, KC and SCC continued receiving support and investments from entrepreneurs and from the local community leaders who convinced the TalTech rector to 
continue KC and SCC's joint activities as the Centre for Blue Economy. Today, the SCC's main R\&D area is marine engineering and vessel hydrodynamics. At the beginning of 2018, TalTech appointed a professor of naval architecture to the Centre for Blue Economy; this was the first Estonian RHEI to open a professorship. In addition, the centre is developing a new specialization on marine bioresources valorization: a product development lab for fish farms and seafood producers. Hence, KC received an opportunity to bounce forward after a risky period.

In small, isolated peripheral regions, the scope of HEI curricula and research activity is usually narrow. KC has focused on the region's potential growth sectors. $\mathrm{KC}$ has regional roots and strong links to local businesses and the community but also a close connection with the mother university when defining the regional focus sectors (Keerberg, 2018). This illustrates the creativity of the HEI organization when improving universities' regional contribution 'at a distance', for example, in generating additional finances.

The key message here is that even small peripheral regions generate specific synergy and creativity that help universities deliver useful services to local industries. However, this synergy can be easily disrupted. The $\mathrm{KC}$ case can be characterized as a constant fight for survival when convincing local stakeholders, national ministry officials and university headquarters of their future operations. In this coevolutionary process, $\mathrm{KC}$ adopted both progressive and defensive strategies. The future perspective of Estonian RHEIs can be characterized as unclear because of the declining number of students, fragmented local authorities and university management reforms.

\section{Case 2. Seinäjoki, Finland}

\section{Regional HEIs in the Finnish Higher Education System}

The Finnish HES is based on two complementary sectors: 13 universities and 23 universities of applied sciences. Traditionally, the universities represent a top-down approach because they were owned by the state until 2010 when they became autonomous. Universities of applied sciences are limited liability companies owned mainly by local authorities, and they focus on a bachelor's level of education, research, development and innovation activities with regional stakeholders.

Additionally, there are six (regional) university consortia (UC) mentioned in the Universities Act, which aims to strengthen universities' 
impact on regional development. Universities see UC as a part of their regional and societal engagement. The central government provides separate funding for them through the coordinating university. The UC were established between 2001 and 2003 in regions with university activities and where there was no university.

\section{South Ostrobothnia and University Consortium of Seinäjoki}

Seinäjoki has 62,500 inhabitants, which is one-third of the population of the region. Seinäjoki has been growing, whereas the rest of the region has seen a decrease in the population. The distance from Seinäjoki to Helsinki is $360 \mathrm{~km}$ (three hours by train). South Ostrobothnia is a semirural region known for its production of food, metal and wood products. The level of education (tertiary degrees) is one of the lowest among the 18 Finnish regions. The number of companies conducting professional innovation activities and R\&D expenditures per capita has been low but growing.

The University Consortium of Seinäjoki (UCS) is located in Seinäjoki, the centre of South Ostrobothnia. UCS was established in 2004 to strengthen the collaboration and provide common services to the universities located in the region; it is coordinated by Tampere University (formerly University of Tampere) because it was the first university that established its unit in Seinäjoki in 1981 (Jumppanen \& Riukulehto, 2015; Kolehmainen \& Alarinta, 2009), focussing mainly on open university education and some practical development projects. The University of Tampere was initially established as the Civic College in Helsinki; it developed into the School of Social Sciences and was moved to Tampere in 1960 in a wave of regional expansion of HE. In Tampere, it grew quite rapidly and was named the University of Tampere in 1966. In 2019, University of Tampere and Tampere University of Technology (TUT) merged and formed the current Tampere University. Currently, Tampere University has operations in Tampere, Pori and Seinäjoki.

The dual nature of the Finnish HES prevails also in South Ostrobothnia. Seinäjoki University of Applied Sciences (SUAS) has 4800 full-time students and 350 staff members, and it started its operations in 1992. The University Association of South Ostrobothnia was founded in 1960 to enhance HE in the region in the hopes of having its own university. Since then, several universities set up their units in Seinäjoki. Still, in the mid-1990s, there was a rising concern among the central local and 
regional authorities that the rural and low-educated region was unprepared for the new knowledge economy and innovation policies that were replacing the traditional, more cohesive regional policy.

At that time, the idea of a regional university network emerged. Local and regional development organizations and young academics from the University Association of South Ostrobothnia and university branch units took leadership to carry these ideas forward (Sotarauta, 2015). The strategic conclusion was that the actual problem was not a missing university of their own but rather the lack of competent people and skilled and plausible academic actors (Sotarauta, 2015). Strengthening the university activities in South Ostrobothnia called for innovative actions: developing a new kind of research culture and cooperation between universities, research institutes, enterprises and local organizations. In 2001, the first programme agreement on Epanet network was signed by five universities and local stakeholders, creating a unique partnership between regional authorities and national academic organizations.

The core of the Epanet network is composed of fixed-term research professors who form externally funded research groups. The aim of the network was to create attractive working conditions for talented scholars. One strategic choice was to focus on research and concentrate professorships on nationally new, interdisciplinary and applied fields relevant for both Finland and South Ostrobothnia (Sotarauta, 2015). The goal to establish 12 professorships exceeded in two years. Here, the strong regional cooperation culture was another key issue in the model because the main financiers were local companies, municipalities and public development organizations (see also Kolehmainen et al., 2016). Therefore, the Epanet model is based on several coevolutionary components between RHEI and its locational region.

Establishing UCS in 2004 was both a regional and national venture: it was national legislation initiated and supported by regional actors. University units located in South Ostrobothnia conducted mostly progressive strategies (performance optimization and adaptive innovation) when following Denyer's (2017) typology. The Epanet network, the heart of UCS, has been the major adaptive innovation. In addition, the aim was to secure the existence of the university activities in the region, that is, acting defensively. Currently, there are 24 research groups led by professors and research directors. More than 80 private partners and several public bodies are financing the Epanet network. Combining different, mainly regional resources is one of the ways to ensure its sustainability. 
As a whole, UCS is a multidisciplinary scientific community of about 90 academics.

\section{UCS and Regional Resilience}

It can be argued that Epanet, UCS and Seinäjoki University of Applied Sciences have contributed to the recent development of South Ostrobothnia and Seinäjoki. The relationships between UCS and the local and regional governmental authorities have been close and their strategies well aligned. The key documents here are from the region's side: South Ostrobothnia's Future Path (2015), Tuoreita eväitä Etelä-Pohjanmaalle (2018) and Smart and outstanding-South Ostrobothnia's strategy of smart specialization (2014). Correspondingly, UCS, SUAS and University Association of South Ostrobothnia have their joint collaboration strategy (Vuorovaikutuksesta vaikuttavuutta, 2013).

Through these planning processes and documents, the selected HE activities of the region have been profiled even more clearly than before but still hold broad focus areas aligned with the region's industrial and business structure. These regional strategic choices have coevolved in close collaboration between the regional authorities and HEIs. When planning new Epanet professorships, future orientation and support for the renewal of the region are important criteria (University Consortium of Seinäjoki, 2019) from the viewpoint of adaptive resilience.

As analysed above, UCS and its surrounding region have coevolved also in terms of resilience. However, there are also some challenges. During the last years, there has been a debate on the regional demographics, labour market and human capital. UCS has made a strategic choice to focus on research and adult education because SUAS has taken care of the degree programmes. Still, the major problem is the decreasing share of 25-34-year-old people holding tertiary degrees (Regional Council of South Ostrobothnia 2017). This is partly a national problem, but South Ostrobothnia is especially lacking behind, resulting in labour shortages in some key fields of the regional economy. This is not a sudden shock or adversity but a result of many factors; hence, focus of UCS on research and development activities and adult education has been challenged.

In this situation, UCS has taken both progressive and defensive actions (Denyer, 2017) or explorative and exploitative actions (March, 1991). On the one hand, it has actively sought new opportunities to expand the educational possibilities, for example, new bachelor's and master's 
programmes and ways to organize internship periods in the region. These new developments may not be radical as such, but they clearly represent a new phase in the development path of UCS. On the other hand, UCS has held to its core strategy based mainly on research and development activities and strong engagement with the regional stakeholders. In terms of OR as conceptualized by Denyer (2017), it is a matter of adaptive innovation and mindful action but also consistency in terms of the core strategies and activities to maintain their identity.

\section{UCS and the Evolving Higher Education System}

The prevailing Universities Act gave the scientific universities increased autonomy in 2010 because they were not owned by the state anymore. However, universities are still heavily dependent on the Ministry of Education and Culture in terms of steering and funding. Finland was hit hard by the global economic crisis in 2008, and the last decade (20102020) has been the age of austerity for Finnish HEIs. It can also be labelled the time of 'structural development'. The Ministry of Education and Culture has encouraged HEIs to become internationally more competitive to ensure the quality and effectiveness of universities' research and teaching, to name few objectives (Välimaa et al., 2014, pp. 45-46). It can be argued that the government funding model has played a crucial role in this respect. Namely, the Finnish university funding model is one of the most performance-oriented models in the world (de Boer et al., 2015). On the other hand, Finnish universities are expected to develop both a knowledge-based economy and societal and civic conditions, for example, by reducing poverty, inequality and social exclusion (Kivistö et al., 2019).

Considerable changes have taken place in the Finnish HES over the last decade: some HEIs have merged, HEIs' internal structures have been regenerated and many universities and universities of applied sciences have reduced or discontinued their regional operations and units. The 'structural development' of the Finnish HES continues. The next significant change in the short or medium term might be the convergence of HE subsystems into a more integrated two-pillar model because there are already new kinds of 'university corporations' in which a scientific university owns a regional university of applied science (e.g. Tampere University). 
UC have a fairly stable position in the Finnish HES, but they cannot take their position for granted because they represent the most decentralized part of the university system. Currently, the core value within the development of the Finnish HES is efficiency, not resilience (cf. Pinheiro \& Young, 2017) albeit there are signs of more balanced ways of thinking. However, for many years, it has been more about streamlining the system than cherishing diversity. These ideas have been transferred from the central government and funding bodies to the HEIs themselves. This is natural because the HES is based on certain funding principles set by the central government, and HEIs adjust their activities to optimize funding.

Also, UCS units are constantly under pressure to prove their utility to their mother universities. Therefore, UCS units have made their connections to their mother universities more aligned with their main objectives. In this respect, the high quality of scientific outputs is a key issue. From the point of view of OR, this calls for progressive- and consistency-driven strategies: the practices of core academic work are developed to optimally utilize resources. However, UCS and other university consortia try to stay original, for example, by being more agile and regionally more engaged as the 'ordinary universities'. It is a matter of diversity and flexibility. In this way, they can also contribute to the resilience of the whole Finnish HES.

\section{Discussion AND CoNCLUSION}

\section{Organizational Resilience of RHEIs}

Estonian and Finnish RHEI schemes provide an interesting organizational model. University colleges and UC differ from traditional research universities: they are smaller, deal largely with applied studies and have proximate relations to local and regional authorities and business communities; still, they have quite directly subordinated to their mother universities. In addition, Finnish UC have internally diverse network structures. RHEIs are constantly under pressure to prove their relevance and quality to the ministerial and university superiors: the rules and standards have been set and are controlled from outside, even if RHEIs own their local and regional funding and other resources.

In both countries, the intensity and scope of regional partnerships depends mainly on local and regional expectations and opportunities 
because mother universities' interest depends largely on national incentives, steering mechanisms and policies. Local businesses form a specific stakeholder group as the collaborative partners for RHEIs. This is emphasized especially in the Estonian case, even if firms are very important funders and collaborative partners in the Finnish case as well. Support from the local and regional public organizations is also valuable. Especially in Finland, the regional public organizations are strongly committed to support and collaborate with the academic organizations in the region.

\section{The Resilience of RHEIs is Rooted in Smallness}

As Vossen (1998) pointed out, small organizations can be agile. The smallest RHEI in Estonia, Kuressaare, has made the best postcrisis progress. In the Estonian case, with a less advanced legislative framework and higher societal dynamism, leadership has played a very vital role in the performance of RHEIs. It has been a constant fight for survival. A small unit can be effective if there is a reasonable labour division: this small unit cannot rely on someone else and can work more intensively because they feel the pressure of the community. Proximity and local buzz also matter (Bathelt et al., 2004), allowing close collaboration and the fast transfer and interpretation of new ideas and knowledge.

Following Denyer's (2017) dimensions of OR, we identify that progressiveness and flexibility are the most important resiliency strategies for RHEIs. Estonian and Finnish RHEIs and their partner networks have existed for about 15 years, so they are still young institutions whose position in the HES is not completely solid, especially in Estonia, where the whole HES has been more volatile. Innovativeness is required to stay on par with or even ahead of traditional HEIs. However, both cases also show the importance of history: there were several previous higher educational bodies that paved the way for the current HEIs. Even though progressiveness and flexibility are the main characteristics of the OR of RHEIs, there are behaviours that are naturally defensive (e.g. counteracting budget cuts or other clearly negative decisions) or consistency driven (preserving strategic emphasis). It is also notable that both cases show an evolution closer to the traditional $\mathrm{HE}$ ideal of the research-teaching nexus (cf. Tight, 2016); the research activities have been strengthened in Kuressaare, and more students will be recruited in Seinäjoki. 


\section{RHEIs Being Resilient Between the Region and HES}

RHEIs are located at the intersection between the region and the HES. In this position, it is possible to recognize the different components creating the conditions for resilience strategies. Next, our empirical observations about coevolutionary processes between RHEIs, regions and the HE system are summed up. Table 10.1 presents the key components of the relationship of a RHEI and the surrounding region and the RHEI and the entire HE system. Table 10.1 introduces how resilience may appear in these relationships in the fields of governance, resources, structure and diversity, agency and leadership and competence building. These categories are at a very general level and are applied from Martin and Sunley's (2015) determinants of regional resilience and are interpreted in the context of RHEIs.

In sum, to be resilient, to survive and thrive, RHEIs must search for balance between the expectations of their region and the HE system, including mother universities. In this respect, RHEIs are organizations that are constantly facing pressures to adapt their operations. These expectations can sometimes be contradictory to each other, like highly ranked scientific research and applied research in cooperation with local business. In their processes of coevolution, RHEIs also meet a tension between progressiveness/defensiveness and flexibility/consistency. On the one hand, they are expected to provide novelty, but on the other hand, they must secure the continuation of existing functions and support regional industrial structures. The resilience of young RHEIs has been mostly based on progressive and flexible strategies because they have been small and agile. Because they are stabilizing and institutionalizing, they also have more accomplishments to defend. 
Table 10.1 The coevolutionary components shaping the resilience of the RHEI, region and HES

\begin{tabular}{|c|c|c|}
\hline Dimensions of coevolution & $\begin{array}{l}\text { Resilient coevolution between } \\
\text { RHEI and region }\end{array}$ & $\begin{array}{l}\text { Resilient coevolution } \\
\text { between RHEI and HES }\end{array}$ \\
\hline Governance & $\begin{array}{l}\text { Trusty and reciprocal } \\
\text { relationships between the } \\
\text { RHEI and the regional } \\
\text { public institutions are } \\
\text { important for both parties. } \\
\text { If the relationship is overly } \\
\text { dependent (see, e.g. Kurikka } \\
\text { et al., 2018), there is } \\
\text { danger of a lock-in situation } \\
\text { (Martin \& Sunley, 2006) } \\
\text { where renewal slows down } \\
\text { or ceases }\end{array}$ & $\begin{array}{l}\text { Very hierarchical and } \\
\text { managerialist governance } \\
\text { reduces the flexibility of } \\
\text { RHEIs and the whole } \\
\text { HES. More networked and } \\
\text { dialogical governance may } \\
\text { vary from extreme } \\
\text { efficiency to extreme } \\
\text { adaptability or robustness }\end{array}$ \\
\hline Resources & $\begin{array}{l}\text { Municipalities and } \\
\text { companies can provide } \\
\text { funding for the RHEI } \\
\text { alongside university or state } \\
\text { funding. RHEIs and their } \\
\text { mother universities have } \\
\text { competences to attract } \\
\text { national and international } \\
\text { research funding to the } \\
\text { region }\end{array}$ & $\begin{array}{l}\text { The HES is based on } \\
\text { certain funding principles } \\
\text { and schemes set by the } \\
\text { central government (see, } \\
\text { e.g. de Boer et al., 2015). } \\
\text { It is quite typical that } \\
\text { different HEIs will adjust } \\
\text { their activities to maximize } \\
\text { their funding. Presumably, } \\
\text { this reduces the diversity } \\
\text { and resilience of the whole } \\
\text { HES. RHEIs need to align } \\
\text { their activities with the } \\
\text { national funding principles } \\
\text { and schemes }\end{array}$ \\
\hline Competence building & $\begin{array}{l}\text { Building competences and } \\
\text { increasing human capital is } \\
\text { one of the key tasks of } \\
\text { HEIs (see, e.g. Vaessen \& } \\
\text { Velde, 2003). If the } \\
\text { educational profile of } \\
\text { RHEIs is compatible with } \\
\text { the labour needs of the } \\
\text { region, this supports } \\
\text { regional competence } \\
\text { building. In addition, } \\
\text { RHEIs, to some extent, } \\
\text { depend on the region's } \\
\text { labour market because they } \\
\text { are specialized employers } \\
\text { themselves }\end{array}$ & $\begin{array}{l}\text { Human capital and } \\
\text { competences are at the core } \\
\text { of the success and resilience } \\
\text { of RHEIs and the HES. } \\
\text { To successfully conduct key } \\
\text { functions, education and } \\
\text { research, competences must } \\
\text { be built persistently }\end{array}$ \\
\hline
\end{tabular}


Table 10.1 (continued)

\begin{tabular}{|c|c|c|}
\hline Dimensions of coevolution & $\begin{array}{l}\text { Resilient coevolution between } \\
\text { RHEI and region }\end{array}$ & $\begin{array}{l}\text { Resilient coevolution } \\
\text { between RHEI and HES }\end{array}$ \\
\hline Structure and diversity & $\begin{array}{l}\text { The structure and } \\
\text { specialization of the regional } \\
\text { industry forms the basis for } \\
\text { economic development and } \\
\text { resilience (see, e.g. Martin } \\
\text { et al., 2016). Matching of } \\
\text { the industrial structure of } \\
\text { the region with the } \\
\text { competences of the RHEI } \\
\text { benefits them both. The } \\
\text { profile of the RHEI can } \\
\text { also contribute to the } \\
\text { renewal of the region's } \\
\text { industrial and business } \\
\text { structure to prevent } \\
\text { lock-in situations (see, e.g. } \\
\text { Benneworth \& Hospers, } \\
\text { 2008) }\end{array}$ & $\begin{array}{l}\text { From the perspective of } \\
\text { system resilience, diversity } \\
\text { is key because it helps the } \\
\text { system adapt to a changing } \\
\text { and complex environment } \\
\text { (Pinheiro \& Young, 2017). } \\
\text { However, there is a natural } \\
\text { dilemma between diversity } \\
\text { and the efficient use of } \\
\text { resources. These notions } \\
\text { hold true both for the } \\
\text { whole HES and individual } \\
\text { RHEIs; indeed, the smaller } \\
\text { institutions have only } \\
\text { limited possibilities to be } \\
\text { diverse }\end{array}$ \\
\hline Agency and leadership & $\begin{array}{l}\text { Regional actors' attitudes } \\
\text { towards RHEIs and their } \\
\text { capabilities to lobby for } \\
\text { common causes will support } \\
\text { making decisions and } \\
\text { mobilizing resources. } \\
\text { RHEIs can provide } \\
\text { insightful people who can } \\
\text { generate institutional } \\
\text { change and provide their } \\
\text { global knowledge networks } \\
\text { (see, e.g. Sotarauta, 2015) }\end{array}$ & $\begin{array}{l}\text { RHEIs have quite limited } \\
\text { possibilities to affect the } \\
\text { whole HES system. } \\
\text { Nonetheless, it is a matter } \\
\text { of agency and leadership } \\
\text { that can reach out from the } \\
\text { regional context (cf. } \\
\text { Benneworth et al., 2017; } \\
\text { Cai \& Liu, 2020). } \\
\text { Representatives of RHEIs } \\
\text { can contribute to the } \\
\text { discussion on the regional } \\
\text { engagement of universities }\end{array}$ \\
\hline
\end{tabular}

\section{REFERENCES}

Arbo, P., \& Benneworh, P. (2007). Understanding the regional contribution of higher education institutions: a literature review. OECD.

Bathelt, H., Malmberg, A., \& Maskell, P. (2004). Clusters and knowledge: Local buzz, global pipelines and the process of knowledge creation. Progress in Human Geography, 28(1), 31-56.

Benneworth, P., \& Hospers, G. (2008). The role of a university in regional renewal: The case of Newcastle. Northern Economic Review, 38, 81-101. 
Benneworth, P., \& Nieth, L. (2018). Universities and regional development in peripheral regions. In P. Benneworth (Ed.), Universities and regional economic development (pp. 1-12). Routledge.

Benneworth, P., Pinheiro, R., \& Karlsen, J. (2017). Strategic agency and institutional change: Investigating the role of universities in regional innovation systems (RISs). Regional Studies, 51(2), 235-248.

Bristow, G., \& Healy, A. (2014). Regional resilience: An agency perspective. Regional Studies, 48(5), 923-935.

de Boer, H., Jongbloed, B., Benneworth, P., Cremonini, L., Kolster, R., Kottmann, A., \& Vossensteyn, H. (2015). Performance-based funding and performance agreements in fourteen higher education systems. Center for Higher Education Policy Studies, University of Twente.

Burnard, K., \& Bhamra, R. (2011). Organisational resilience: Development of a conceptual framework for organisational responses. International Journal of Production Research, 49(18), 5581-5599.

Cai, Y., \& Liu, C. (2020). The role of university as institutional entrepreneur in regional innovation system: Towards an analytical framework. In A. Daniel, A. Teixeira, \& M. Preto (Eds.), Examining the role of entrepreneurial universities in regional development (pp. 133-155). IGI Global.

Charles, D. (2016). The rural university campus and support for rural innovation. Science and Public Policy, 43(6), 763-773.

Clark, B. R. (1983). The higher education system. Academic organization in crossnational perspective. University of California Press.

Clark, B. R. (1998). Creating entrepreneurial universities: Organizational pathways of transformation. Elsevier Science Ltd.

Denyer, D. (2017). Organizational resilience. A summary of academic evidence, business insights and new thinking. British Standards Institution and Cranfield University. https://www.cranfield.ac.uk/ /media/images-for-new-website/ som-media-room/images/organisational-report-david-denyer.ashx. Accessed 13 Dec 2019.

DiMaggio, P. (1988). Interest and agency in institutional theory. In L. Zucker (Ed.), Institutional patterns and culture (pp. 3-22). Ballinger.

Grillitsch, M., \& Asheim, B. (2018). Place-based innovation policy for industrial diversification in regions. European Planning Studies, 26(8), 1638-1662.

Gunasekara, C. (2006). Reframing the role of universities in the development of regional innovation systems. The Journal of Technology Transfer, 31(1), 101113.

Hedin, S. (Ed.) (2009). Higher education institutions as drivers of regional development in the Nordic countries. Nordregio. https://archive.nordregio.se/ Global/Publications/Publications\%202009/WP2009_3.pdf. Accessed 13 Dec 2019. 
Isaksen, A. (2015). Industrial development in thin regions: Trapped in path extension? Journal of Economic Geography, 15(3), 585-600.

Jumppanen, A., \& Riukulehto, S. (2015). Puskasta framille: Viisikymmentä vuotta tekniikan koulutusta Seinäjoella. Seinäjoen ammattikorkeakoulun julkaisusarja B. Raportteja ja selvityksiä 112. Seinäjoen ammattikorkeakoulu.

Karlsen, J., Isaksen, A., \& Spilling, O. R. (2011). The challenge of constructing regional advantages in peripheral areas: The case of marine biotechnology in Troms $\varnothing$, Norway. Entrepreneurship and Regional Development, 23(3-4), 235-257.

Keerberg, A. (2018). Higher education institutions at the periphery of the periphery: Creating sustainable economic development in Estonia. In P. Benneworth (Ed.), Universities and regional economic development (pp. 141158). Routledge.

Kivistö, J., Pekkola, E., Nordstrand Berg, L., FossHansen, H., Geschwind, L., \& Lyytinen, A. (2019). Performance in higher education institutions and its variations in Nordic policy. In R. Pinheiro, L. Geschwind, H. Foss Hansen, \& K. Pulkkinen (Eds.), Reforms, organizational change and performance in higher education: A comparative account from the Nordic countries (pp. 37-62). Palgrave MacMillan.

Kolehmainen, J., \& Alarinta, J. (2009). University Consortium of Seinäjoki, Finland: Bringing South Ostrobothnia to the knowledge economy. Regions Magazine, 273(1), 17-19.

Kolehmainen, J., Irvine, J., Stewart, L., Karacsonyi, Z., Szabó, T., Alarinta, J., \& Norberg, A. (2016). Quadruple helix, innovation and the knowledge-based development: Lessons from remote, rural and less-favoured regions. Journal of the Knowledge Economy, 7(1), 23-42.

Kurikka, H., Kolehmainen, J., \& Sotarauta, M. (2018). Constructing regional resilience in a knowledge economy crisis: The case of the Nokia-led ICT industry in Tampere. In Benneworth, P. (Ed.), Universities and regional economic development (pp. 163-179). Routledge.

Lewin, A. Y., \& Volberda, H. W. (1999). Prolegomena on coevolution: A framework for research on strategy and new organizational forms. Organization Science, 10(5), 519-534.

March, J. G. (1991). Exploration and exploitation in organizational learning. Organization Science, 2(1), 71-87.

Martin, R. (2012). Regional economic resilience, hysteresis and recessionary shocks. Journal of Economic Geography, 12(1), 1-32.

Martin, R., \& Sunley, P. (2006). Path dependence and regional economic evolution. Journal of Economic Geography, 6(4), 395-437.

Martin, R., \& Sunley, P. (2015). On the notion of regional economic resilience: Conceptualization and explanation. Journal of Economic Geography, 15(1), $1-42$. 
Martin, R., Sunley, P., Gardiner, B., \& Tyler, P. (2016). How regions react to recessions: Resilience and the role of economic structure. Regional Studies, $50(4), 561-585$.

Moran, K. A. (2016). Organizational resilience: Sustained institutional effectiveness among smaller, private, non-profit US higher education institutions experiencing organizational decline. Work, 54(2), 267-281. https://doi.org/ 10.3233 /WOR-162299

OECD. (2007). Higher education and regions. Globally competitive, locally engaged. OECD.

OECD. (2019). Benchmarking higher education system performance. OECD.

Olsen, J.P. (2007). The institutional dynamics of the European university. In P. Maassen \& J.P. Olsen (Eds.). University dynamics and European integration (pp. 25-54). Springer.

Pike, A., Dawley, S., \& Tomaney, J. (2010) Resilience adaptation and adaptability. Cambridge Journal of Regions Economy and Society, 3(1), 59-70.

Pinheiro, R., \& Young, M. (2017). The university as an adaptive resilient organization: A complex systems perspective. In Huisman, J. \& Tight, M. (Eds.), Theory and method in higher education research (Vol. 3, pp. 119-136). Emerald.

Postiglione, G. A. (2011). Global recession and higher education in eastern Asia: China, Mongolia and Vietnam. Higher Education, 62(6), 789-814.

Raagmaa, G., \& Keerberg, A. (2017). Regional higher education institutions in regional leadership and development. Regional Studies, 51(2), 260-272.

Regional Council of South Ostrobothnia (2017). Innovaatiotoiminnan tilannekuva 2017. (Situation Picture of Regional Innovation Activities 2017). https://www.epliitto.fi/images/IKEP\%20tilannekuva\%2021\%2012\%202017. pdf. Accessed 13 Dec 2019.

Reidolf, M., Keerberg, A., \& Hartikainen, A. (2011). Universities role in the region: The case of Saaremaa Small Craft Competence Centre. In G. Prause \& U. Venesaar (Eds.), University-business cooperation. Berliner Wissenschafts-Verlag.

Rothblatt, S., \& Wittrock, B. (1993). The European and American university since 1800: Historical and sociological essays. Cambridge University Press.

Saare Development Centre. (2018). Saare maakonna ettevõtluse ja ettevõtluskeskkonna kaardistamine ning ïlevaade (Mapping and overview of Saare County entrepreneurship and business environment). https:// www.sasak.ee/application/files/6515/6258/9125/2019_06_03_Saare_m aakonna_ettevotluse_ja_ettevotluskeskkonna_kaardistamine_ja_ulevaade_.pdf. Accessed 19 Dec 2019.

Sääsk, H. (2018). Eesti laevaehitusettevõtted 2017 (Estonian Shipbuilding Companies 2017). https://www.scc.ee/ee/wp-content/uploads/2019/01/ 
Eesti-laevaehitusettev\%C3\%B5tted-2017.-TalTech-V\%C3\%A4ikelaevaehitusekompetentsikeskuse-uuring.pdf. Accessed 13 Dec 2019.

Selznick, P. (1984). Leadership in administration: A sociological interpretation. University of California Press.

Sotarauta, M. (2014). Territorial knowledge leadership in policy networks: A peripheral region of South Ostrobothnia, Finland as a case in point. In $\mathrm{R}$. Rutten, P. Benneworth, D. Irawati, \& F. Boekema (Eds.), The social dynamics of innovation networks (pp. 42-59). Routledge.

Smart and outstanding - South Ostrobothnia's strategy of smart specialisation (2014). Regional Council of South Ostrobothnia. Seinäjoki. Accessed 24 Feb 2020.

Sørensen, M. P., Bloch, C., \& Young, M. (2016). Excellence in the knowledgebased economy: From scientific to research excellence. European Journal of Higher Education, 6(3), 217-236.

Sotarauta, M. (2015). Leadership and the city. Power, strategy and networks in the making of knowledge cities. Routledge.

Sotarauta, M., \& Kautonen, M. (2007). Co-evolution of the Finnish national and local innovation and science arenas: Towards a dynamic understanding of multi-level governance. Regional Studies, 41(8), 1085-1098.

Sotarauta, M., \& Srinivas, S. (2006). Co-evolutionary policy processes: Understanding innovative economies and future resilience. Futures, 38(3), 312-336.

South Ostrobothnia's Future Path (Regional Development Plan 2040 \& Regional Programme 2014-2017) (2015). Regional Council of South Ostrobothnia.

Stensaker, B., \& Benner, M. (2013). Doomed to be entrepreneurial: Institutional transformation or institutional lock-ins of 'new' universities? Minerva, 51(4), 399-416.

Stensaker, B., Välimaa, J., \& Sarrico, C. (2012). Managing reform in universities: The dynamics of culture, identity and organisational change. Palgrave Macmillan.

Tapper, T., \& Palfreyman, D. (2011). Oxford, the collegiate university: Conflict, consensus and continuity. Springer.

Tödtling, F., \& Trippl, M. (2005). One size fits all? Towards a differentiated regional innovation policy approach. Research Policy, 34(8), 1203-1219.

Trippl, M., Asheim, B., \& Miörner, J. (2016). Identification of regions with less-developed research and innovation systems. In Parrilli, M. D, Fitjar, R. D. \& Rodríguez-Pose, A. (Eds.), Innovation drivers and regional innovation strategies (pp. 39-60). Routledge.

Tight, M. (2016). Examining the research/teaching nexus. European Journal of Higher Education, 6(4), 293-311.

TIPS. (2015). The Research and Innovation Policy Monitoring Programme. http: / $/$ www.tips.ut.ee $/$ index.php? module $=32 \& o p=1 \& i d=3683$. Accessed 13 Dec 2019. 
Tuoreita eväitä Etelä-Pohjanmaalle. Maakuntaohjelma 2018-2021. (Regional Plan 2018-2021) (2018). Etelä-Pohjanmaan liitto. Regional Council of South Ostrobothnia.

University Consortium of Seinäjoki. (2019). Seinäjoen yliopistokeskuksen toimintakertomus 2018 (Annual report of University Consortium of Seinäjoki 2018). https://www.ucs.fi/wp-content/uploads/UCS_toimintakertomus_2 018_web.pdf. Accessed 13 Dec 2019.

Välimaa, J., Aittola, H., \& Ursin, J. (2014). University mergers in Finland: Mediating global competition. New Directions for Higher Education, 2014(168), $41-53$.

Vaessen, P.M.M., \& van der Velde, M. (2003). University knowledge transfer through social and professional embeddedness: A case study. In R. Rutten, F. Boekema, \& E. Kuijpers (Eds.), Economic geography of higher education: knowledge infrastructure and learning regions (pp. 87-109). Routledge.

Vossen, R. W. (1998). Relative strengths and weaknesses of small firms in innovation. International Small Business Journal, 16(3), 88-94.

Vukasovic, M., Maassen, P., Nerland, M., Pinheiro, R., Stensaker, B., \& Vabø, A. (2012). Effects of higher education reforms: Change dynamics. Sense Publishers.

Vuorovaikutuksesta vaikuttavuutta. Etelä-Pohjanmaan korkeakoulustrategia 2020 (The Regional HEI strategy of South Ostrobothnia). (2013). Seinäjoki University of Applied Sciences, University Association of South Ostrobothnia, University Consortium of Seinäjoki.

Ülikoolide (2008). Ülikoolide ühiste kavatsuste leping regionaalsete kompetentsikeskuste loomise kohta. (The Agreement of Common Intent of Universities on the Establishment of Regional Competence Centres). Memorandum, Rectors' Conference, Tallinn, 24.11.2008.

Young, M., \& Pinheiro, R. (2022). The post-entrepreneurial University: The case for Resilience in Higher Education. In Pinheiro, R., Frigotto, L., \& Young, M. (Ed.), Towards resilient organizations and societies: A cross-sectoral and multidisciplinary perspective (pp. 179-200). Palgrave. 
Open Access This chapter is licensed under the terms of the Creative Commons Attribution 4.0 International License (http://creativecommons.org/licenses/ by $/ 4.0 /$ ), which permits use, sharing, adaptation, distribution and reproduction in any medium or format, as long as you give appropriate credit to the original author(s) and the source, provide a link to the Creative Commons license and indicate if changes were made.

The images or other third party material in this chapter are included in the chapter's Creative Commons license, unless indicated otherwise in a credit line to the material. If material is not included in the chapter's Creative Commons license and your intended use is not permitted by statutory regulation or exceeds the permitted use, you will need to obtain permission directly from the copyright holder.

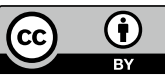

